\title{
ADAPTABILITY TO VARIABLE WEATHER CONDITIONS AND IRRIGATION RESPONSE IN NS SUNFLOWER HYBRIDS
}

\author{
Livija Maksimović* \\ Institute of Field and Vegetable Crops, 21000 Novi Sad, Maksima Gorkog 30, \\ Serbia and Montenegro
}

Received: June 24, 2005 Accepted: November 22, 2005

\section{SUMMARY}

Sunflowers are annually grown in Serbia at 150,000 to 200,000 ha, with average yields of about $2.0 \mathrm{t} / \mathrm{ha}$. Yield variations are due to uneven and unfavorably distributed rainfall. Under irrigation, yields reach $3 \mathrm{t} / \mathrm{ha}$ in commercial production and 4 to $5 \mathrm{t} / \mathrm{ha}$ in experiments.

In 2000-2004, two sunflower hybrids developed at Novi Sad Institute were tested in irrigation trials on a chernozemic soil.

In 2000, which was dry, the average yields with and without irrigation were $5.04 \mathrm{t} / \mathrm{ha}$ and $3.97 \mathrm{t} / \mathrm{ha}$, respectively. In 2001, which was rainy, yields with and without irrigation were similar, around 3 t/ha. In 2002, which was moderately dry, the average yields with and without irrigation were similar, around $4.5 \mathrm{t} / \mathrm{ha}$, due to development of diseases in irrigation. In 2003, which was exceptionally warm and dry, sunflower yields were reduced because of a short growing season. The average irrigation effect for the two tested hybrids was $27 \%$, and as much as $51 \%$ for the hybrid Dukat. In 2004 , which was very favorable for production, sunflower yields were uniform and quality was high.

Irrigation practice positively affected oil yield of both hybrids, especially in the dry years. These results justify the application of irrigation practice in sunflower production.

The hybrid NS-H-111 exhibited high adaptability and yield stability when grown under variable weather conditions. The hybrid Dukat showed to be suitable for late planting and double cropping when grown in irrigation.

Key words: sunflower, NS hybrids, irrigation, water requirement, grain yield, oil content, oil yield

\section{INTRODUCTION}

Sunflowers are grown at a comparatively large acreage in Serbia and Montenegro. In recent years, the acreage has stabilized at 200,000 ha and the average yield

\footnotetext{
* Corresponding author: Phone: +381 214898 170, e-mail: livija@ifvens.ns.ac.yu
} 
at about 2 t/ha. About $84 \%$ of the total acreage are planted in the Vojvodina Province (Škorić et al., 1996).

In average years, high yields of sunflower are obtained without irrigation. Accordingly, Bošnjak and Marinković (1992) recommended that sunflower should not be irrigated. In practice, sunflowers are irrigated at a very limited acreage. However, the sunflower requirement for water is high (400 to $500 \mathrm{~mm}$ ) and its yield level depends on the amount and distribution of rainfall during growing season (Gatto et al., 1980). According to Dragović and Maksimović (1995), there are two major limiting factors to high yield performance of sunflowers, fungal diseases in rainy and cool years and water shortage in dry years.

Because it is capable of taking up water from deep soil layers (up to $2 \mathrm{~m}$ ), the sunflower is tolerant to drought. Still, in years with insufficient and unfavorably distributed rainfall, sunflower yield is significantly reduced because the sunflower has large green bulk and leaf area. Irrigation practice both increases and stabilizes the yield performance of sunflower.

To successfully grow sunflowers in a region, it is important to make a good choice of hybrid and to apply cultivation practices on time (Crnobarac et al., 1997). When developing new hybrids, special attention should be given to their adaptability to a variety of environmental conditions (Škorić, 1988). New NS sunflower hybrids are as a rule more productive than the older ones, which is in part due to their increased adaptability.

The new NS hybrids are regularly entered in irrigation trials, to assess their maximum performance, yield stability, effect of irrigation and resistance to drought and diseases. Irrigation trials are conducted each year, under varying climatic conditions. This paper discusses the performances of the hybrids Dukat and NS-H111 , which serve as internal standards in the trials.

\section{METHOD}

Field trials were conducted in the period 2000-2004, at Rimski Šančevi experiment field of Institute of Field and Vegetable Crops in Novi Sad, on the loamy chernozemic soil with favorable water-physical and chemical properties. Each year we tested six to seven NS sunflower hybrids. While the tested hybrids were replaced by others after a round of study, Dukat and NS-H-111 remained in the trials for all five years.

Fertilization was performed in the fall, with $400 \mathrm{~kg}$ NPK (15:15:15) or $60 \mathrm{~kg}$ active substance/ha. One top dressing was performed in the course of growing season, with $53 \mathrm{~kg} \mathrm{~N} / \mathrm{ha}$. Planting was performed in the first half of April.

Morphological observations were done during growing season. Plant height and head diameter were measures before harvest. Disease incidence was monitored in the course of growing season. As the obtained results are quite voluminous, we 
shall deal in this paper with only three productivity parameters (seed yield, oil content in seed and oil yield/ha).

Sprinkling irrigation was scheduled on the basis of soil moisture, at $60-65 \%$ of field water capacity (FWC). Number of irrigations and amounts of irrigation water are shown in Table 1.

Table 1: Irrigation schedules and amounts of supplied water $(\mathrm{mm})$

\begin{tabular}{ccccc}
\hline 2000 & 2001 & 2002 & 2003 & 2004 \\
\hline 1 June -40 & 18 July -40 & 21 June -60 & 7 May -25 & 2 July -45 \\
9 June -40 & 9 August -60 & 4 July -60 & 6 June -60 & 17 July -60 \\
23 June -50 & & 22 July -60 & 20 June 50 & \\
21 July -50 & & 8 August -60 & 5 July -30 & \\
\hline Total -180 & Total -100 & Total -240 & Total -165 & Total -105 \\
\hline
\end{tabular}

Oil content in seed was determined in an NMR analyzer, in four replications.

\section{RESULTS AND DISCUSSION}

Water requirement of sunflower depends on the soil and climatic conditions of location and the biological characteristics of hybrid. In the agroclimatic conditions of Serbia and Montenegro, the potential evapotranspiration (ETP) of sunflower is $470 \mathrm{~mm}$ (Dragović et al., 1996). A group of sunflower hybrids in an irrigation trial conducted in the period 1991-1995 had the average ETP of $497 \mathrm{~mm}$, with annual variations from 440 to $560 \mathrm{~mm}$ (Maksimović et al., 1998). Long-term studies of Vučić and Bošnjak (1988) set the ETP of sunflowers grown under variable agroclimatic conditions at $440 \mathrm{~mm}$. Bošnjak (1993) reported the ETP of $450 \mathrm{~mm}$ (410$490 \mathrm{~mm}$ ) and Unger (1990) $430 \mathrm{~mm}$.

In the study period (2000-2004), the average sunflower requirement calculated on the basis of water balance was $457 \mathrm{~mm}$. The actual requirements varied from $430 \mathrm{~mm}$ in 2001 (a rainy year) to $484 \mathrm{~mm}$ in 2000 (a very dry year).

Sunflowers effectively use soil water from winter reserve, which allows them to withstand drought without noteworthy yield reduction. According to Maksimović and Dragović (1997), sunflowers grown on a chernozemic soil took up about 200 $\mathrm{mm}$ of water from the soil layer $0-200 \mathrm{~cm}$, which made $40-50 \%$ of their total requirement. A similar statement had been made by Cox and Jolliff (1986). In the dry year of 2000, sunflowers took up $244 \mathrm{~mm}$ of water from winter reserve in the soil layer 0-200 cm, $180 \mathrm{~mm}$ from irrigation and only $108 \mathrm{~mm}$ from natural rainfall. Sunflowers take up much smaller amounts of winter moisture in rainy years. In 1999, for example, they took up only $55 \mathrm{~mm}$ of winter moisture (Dragović et al., 2001).

The study period was exceedingly variable with regard to the amounts and distribution of rainfall during growing season and annual rainfall (Table 2), as well as regarding temperatures (Table 3 ). 
Table 2: Rainfall sums at Rimski Šančevi experiment field (mm)

\begin{tabular}{lcccccc}
\hline Month & \multicolumn{5}{c}{ Year } & $\begin{array}{c}\text { Long-term } \\
\text { average, } \\
19064-2000\end{array}$ \\
\cline { 2 - 6 } Pre-growing season rainfall & 301 & 2001 & 2002 & 2003 & 2004 & 249 \\
April & 24 & 127 & 26 & 8 & 112 & 47 \\
May & 39 & 75 & 87 & 23 & 89 & 59 \\
June & 28 & 233 & 27 & 31 & 97 & 84 \\
July & 29 & 56 & 33 & 60 & 63 & 70 \\
August & 5 & 30 & 55 & 30 & 39 & 59 \\
September & 13 & 162 & 46 & 84 & 42 & 41 \\
\hline Growing season & 138 & 683 & 274 & 236 & 442 & 360 \\
Annual sum & 270 & 931 & 465 & 502 & 814 & 608 \\
\hline
\end{tabular}

Table 3: Mean monthly air temperatures during growing season at Rimski Šancevi experiment field $\left({ }^{\circ} \mathrm{C}\right)$

\begin{tabular}{lcccccc}
\hline Month & \multicolumn{5}{c}{ Year } & $\begin{array}{c}\text { Long-term average, } \\
1964-2000\end{array}$ \\
\cline { 2 - 5 } & 2000 & 2001 & 2002 & 2003 & 2004 & 11.3 \\
\hline April & 14.9 & 11.2 & 11.7 & 10.9 & 19.4 & 16.7 \\
May & 18.5 & 17.8 & 19.1 & 20.6 & 15.2 & 19.7 \\
June & 21.3 & 18.2 & 21.7 & 24.0 & 19.8 & 21.3 \\
July & 22.1 & 22.3 & 23.6 & 22.6 & 22.0 & 20.8 \\
August & 24.0 & 22.7 & 22.2 & 24.6 & 21.7 & 16.8 \\
September & 17.8 & 16.1 & 17.0 & 17.2 & 16.2 & 17.8 \\
\hline Growing season & 19.8 & 18.1 & 19.2 & 20.0 & 17.9 & \\
\hline
\end{tabular}

Although with a high pre-growing season rainfall, the year 2000 was outstandingly dry. The total rainfall during growing season was only $138 \mathrm{~mm}$ and its distribution was unfavorable. The deviation from the long-term annual sum was significant, $222 \mathrm{~mm}$. Because of that, four irrigations had to be performed that year, with $180 \mathrm{~mm}$ of water. Such climatic conditions were favorable for irrigated sunflowers, as indicated by maximum yields obtained by the hybrids Dukat and NS-H-111 in irrigation, 4.62 t/ha and 5.46 t/ha, respectively (Table 4).

The year 2001 differed entirely from the previous one. The growing season and total annual rainfalls were $683 \mathrm{~mm}$ and $931 \mathrm{~mm}$, respectively. Those were record rainfalls for the studied location. The two irrigations, with a total of $100 \mathrm{~mm}$ of water, had no effect on yield performance. Low temperatures and rains in September caused intensive outbreaks of diseases which in their turn brought significant yield reductions.

The year 2002 was moderately dry, with the sum of rainfall during growing season of $274 \mathrm{~mm}$ and a relatively favorable distribution of rainfall. However, due to high air temperatures (Table 3), there occurred four dry spells, when sunflowers had to be irrigated. The irrigation norm was $240 \mathrm{~mm}$ (Table 1) and it had no signif- 
icant effect on yield performance. Rains fell several days after the irrigations, providing water and thus increasing the yield in the non-irrigated control.

There were $236 \mathrm{~mm}$ of rain in the course of the 2003 growing season. The difference in relation to the long-term average was $-124 \mathrm{~mm}$ (Table 2). Drought started at the very beginning of the growing season, it was intensive and it persisted till the end of the season. The air temperature was considerably above the long-term average, by $2.2^{\circ} \mathrm{C}$ (Table 3 ), which resulted in the occurrence of air drought which further intensified the soil drought. The combination of drought and high temperatures caused premature wilting in the non-irrigated part of the experiment and early maturation in the irrigated part of the experiment. Oil synthesis was interrupted by early leaf shedding.

The year 2004 had very favorable conditions for crop production in the Vojvodina Province. High yields and excellent quality were achieved in all crops including sunflower.

Table 4: Sunflower yields (t/ha) depending on hybrid and irrigation practice

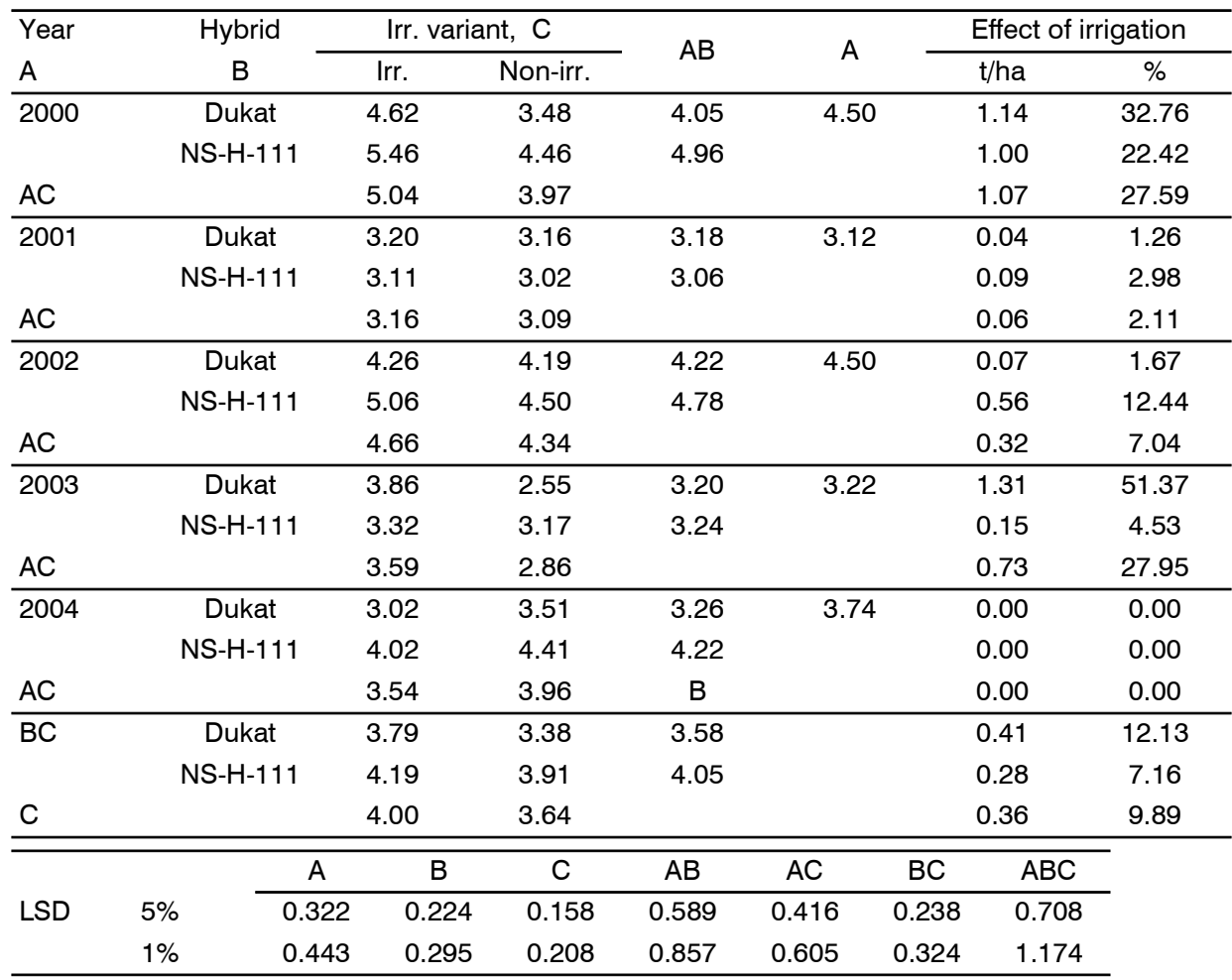

Sunflower yield performance depends on weather conditions during growing season and the genetic yield potential of the hybrid grown (Flagella et al., 2002). Drought in early stages of growth negatively affects yield performance. Regarding the period of seed filling, excessive rainfall and low temperatures are more detri- 
mental for yield performance than insufficient rainfall, as demonstrated by the rainy year 2001 and the dry year 2000 (Table 4). The tested hybrids had a poorer performance in 2001 than in 2000 by 1.38 tha or $44 \%$. In the exceedingly dry year 2000 , the average yield without irrigation was $3.97 \mathrm{t} / \mathrm{ha}$, the average yields of the hybrids ranging from 3.48 to 4.46 t/ha. The rainfall shortage during the 2000 growing season was $362 \mathrm{~mm}$, which was partially compensated by the uptake of 254 $\mathrm{mm}$ of water from the soil layer $0-200 \mathrm{~cm}$. This explains the high yields obtained without irrigation. Thanks to such conditions, the yields were further increased on account of the absence of fungal diseases.

Because of a well-developed root system, the sunflower plant efficiently takes up water from deep soil layers. Thus, the effect of irrigation comes to expression only in very dry years, such as the year 2000. In that year, the average yield in irrigation was $5.04 \mathrm{t} / \mathrm{ha}$. The average effect of irrigation was $1.07 \mathrm{t} / \mathrm{ha}$ or $28 \%$. Effect of irrigation is lower in sunflowers than in most other crops. Bošnjak and Marinković (1992) reported that, in a dry year, irrigation practice increased the yields of sunflower and soybean by $34 \%$ and $80 \%$, respectively. Because of their high tolerance to drought, commercial sunflowers yield about 2 t/ha in dry years (Škorić et al., 1993). This report was in agreement with the results of our study, in which the sunflower yield performance never went below $2.5 \mathrm{t} / \mathrm{ha}$, even in the most unfavorable years (Table 4). NS sunflower hybrids had exhibited similar reactions to stress conditions in earlier trials. In the irrigation trial in the dry year of 1992, early and late NS hybrids outyielded the control by 31 and 57\%, respectively (Stone et. al., 1996; Maksimović and Dragović, 1997). A long-term study of Dragović et al. (1997) showed that irrigation practice increased the yield of sunflowers from 30 to $40 \%$, and as much as $80 \%$ in extremely dry years.

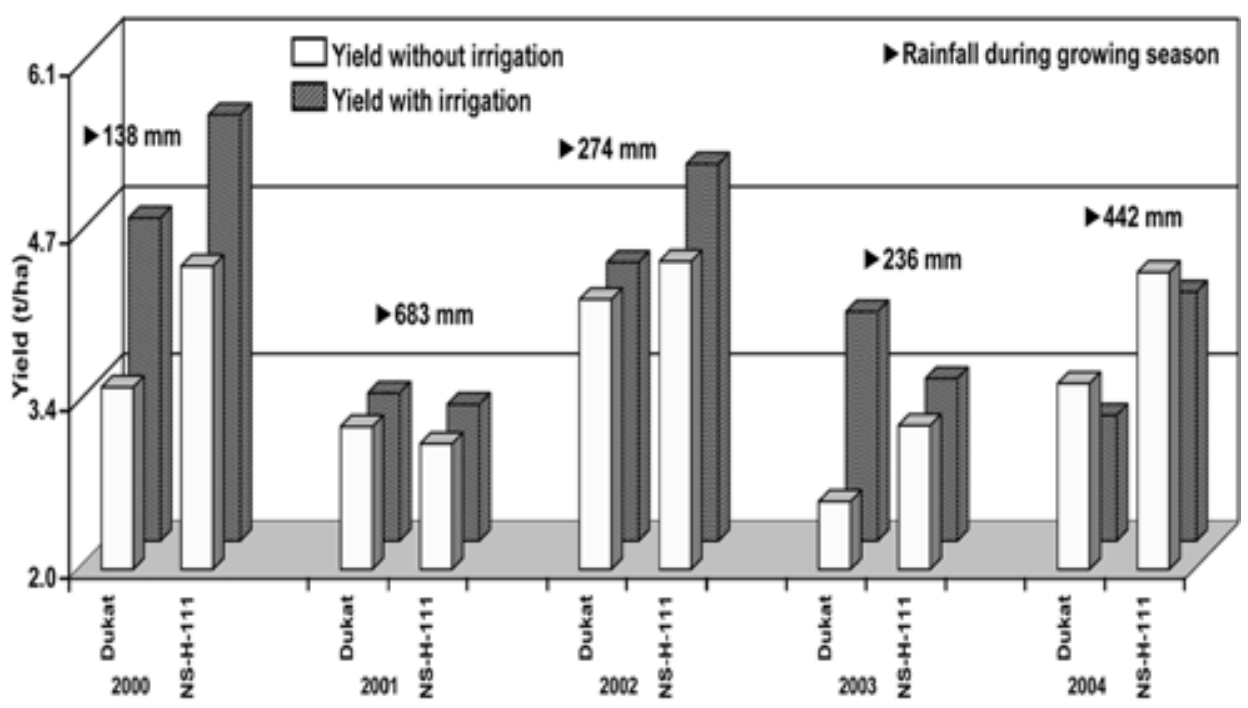

Figure 1: Sunflower yields (t/ha) with and without irrigation 
In the rainy year of 2001, the average yields with and without irrigation were 3.16 and 3.09 t/ha, respectively. Two irrigations were performed which practically had no effect on sunflower yield performance. These results supported the report of Dragović (1992) who concluded that sunflowers need not be irrigated in regions with a variable climate because similar yields are obtained with and without irrigation in moderately dry years, while no large difference can be obtained between irrigation and dry farming in dry years. This conclusion was confirmed by the yields obtained in 2002. In that year, the rainfall during the growing season was $279 \mathrm{~mm}$. A total of $240 \mathrm{~mm}$ of water were added in four irrigations but it had no significant effect on sunflower yield performance. The average yields with and without irrigation were 4.66 and $4.34 \mathrm{t} / \mathrm{ha}$, respectively. In the case of the hybrid NS-H-111, the effect of irrigation was $12 \%$ (Figure 1 ).

On the five-year average, the yields of the two hybrids with and without irrigation were 4.00 and 3.64 t/ha, respectively. The hybrid NS-H-111 exhibited smaller annual yield variations, similarly to results of numerous large-plot trials conducted in our country and several countries in Europe (Škorić et al., 2005).

Oil content in sunflower seeds depends on weather conditions, intensity of fungal diseases and hybrid. In this study, the lowest average oil content, $44.85 \%$, was obtained in 2002 and it was mainly due to fungal diseases. The highest average oil content, 51.72\%, was obtained in 2001 (Table 5).

Table 5: Oil percentages and oil yields (kg/ha) of NS sunflower hybrids in irrigation trials

\begin{tabular}{|c|c|c|c|c|c|c|c|}
\hline \multirow{2}{*}{$\begin{array}{l}\text { Year, } \\
\text { A }\end{array}$} & \multirow{2}{*}{$\begin{array}{l}\text { Hybrid, } \\
\text { B }\end{array}$} & \multicolumn{3}{|c|}{ Oil content (\%) } & \multicolumn{3}{|c|}{ Oil yield (kg/ha) } \\
\hline & & Irr. & Non-irr. & Average & Irr. & Non-irr. & Average \\
\hline \multirow[t]{2}{*}{2000} & Dukat & 46.21 & 48.69 & 47.45 & 2135 & 1694 & 1914 \\
\hline & NS-H-111 & 47.09 & 48.72 & 47.90 & 2571 & 2173 & 2372 \\
\hline$A C$ & & 46.65 & 48.70 & 47.68 & 2353 & 1934 & 2143 \\
\hline \multirow[t]{2}{*}{2001} & Dukat & 52.72 & 53.49 & 53.10 & 1687 & 1690 & 1688 \\
\hline & NS-H-111 & 50.71 & 49.95 & 50.33 & 1577 & 1508 & 1542 \\
\hline$A C$ & & 51.72 & 51.72 & 51.72 & 1632 & 1599 & 1615 \\
\hline \multirow[t]{2}{*}{2002} & Dukat & 44.10 & 42.03 & 43.06 & 1877 & 1761 & 1819 \\
\hline & NS-H-111 & 46.86 & 46.49 & 46.68 & 2371 & 2092 & 2232 \\
\hline$A C$ & & 45.48 & 44.26 & 44.87 & 2124 & 1926 & 2025 \\
\hline \multirow[t]{2}{*}{2003} & Dukat & 47.02 & 48.79 & 47.90 & 1815 & 1244 & 1530 \\
\hline & NS-H-111 & 50.11 & 51.62 & 50.86 & 1665 & 1636 & 1650 \\
\hline$A C$ & & 48.56 & 50.20 & 49.38 & 1740 & 1440 & 1590 \\
\hline \multirow[t]{2}{*}{2004} & Dukat & 43.25 & 43.89 & 43.57 & 1306 & 1540 & 1423 \\
\hline & NS-H-111 & 47.19 & 49.56 & 48.38 & 1897 & 2186 & 2042 \\
\hline$A C$ & & 45.22 & 46.72 & 45.97 & 1602 & 1863 & 1732 \\
\hline \multirow[t]{2}{*}{$\mathrm{BC}$} & Dukat & 46.66 & 47.38 & 47.02 & 1764 & 1586 & 1675 \\
\hline & NS-H-111 & 48.39 & 49.27 & 48.83 & 2016 & 1919 & 1968 \\
\hline C & & 47.53 & 48.32 & 47.92 & 1890 & 1752 & 1821 \\
\hline
\end{tabular}


As diseases were not intensive in the other years, the oil percentages were high, $48.35 \%$ without irrigation and $47.53 \%$ in irrigation (Table 5). Irrigation decreased the oil percentage by $0.79 \%$ on average. A similar reduction rate was observed in an earlier study of Dragović (1992) and Goksoy et al. (2004).

Oil yield is the chief indicator of productivity of sunflower hybrids. It is positively correlated with seed yield and oil content in seed. In the period 2002-2004, NS-H-111 had the highest oil yield in the domestic commercial production (Škorić et al., 2005). In our trial, NS-H-111 was better than Dukat, with the average oil yield of $1.97 \mathrm{t} / \mathrm{ha}$ (Table 5). Irrigation practice positively affected oil yields of the two hybrids, especially in dry years (Plaut, 1995).

Škorić et al. (2001) reported that NS-H-111 is highly adaptable and capable of producing high yields under a large variety of agroclimatic conditions. Good results have been obtained with this hybrid in Romania, Bulgaria, the Ukraine, Russia and Moldavia. Among 23 NS sunflower hybrids grown in 11 localities in 2002, NS-H111 achieved the highest oil yield (Škorić et al., 2003). The results of out trial are in agreement with the above.

\section{CONCLUSION}

In the five-year irrigation trial, the two NS hybrids, Dukat and NS-H-111, efficiently used soil water from the layer $0-200 \mathrm{~cm}$, proving that their root systems are well developed. Such root systems make them superior to most field and vegetable crops in respect to drought resistance. The water requirements of the hybrids, which varied with weather conditions, ranged between 440 and $500 \mathrm{~mm}$, or 457 $\mathrm{mm}$ on average. Effect of irrigation was expressed only in dry years. Yield increase by irrigation was significant, $27 \%$ on average. In the case of the hybrid Dukat, the increases ranged from 33 to $51 \%$.

Yield performance of the tested NS sunflower hybrids depended to large measure on weather conditions during growing season and intensity of occurrence of fungal diseases. The average yield for the study period was $3.82 \mathrm{t} / \mathrm{ha}$, the average annual yields ranging from 3.12 to 4.50 t/ha. Highest yields were achieved in the year 2000 by the hybrid NS-H-111, 5.46 t/ha in irrigation and 4.46 t/ha without irrigation.

The average oil content was $47.92 \%$ and it was only slightly lower in irrigation. Depending on weather conditions of the year, oil contents ranged from $44.87 \%$ in 2002 to $51.72 \%$ in 2001 . Irrigation practice positively affected oil yield of both hybrids, especially in dry years. These results justify the application of this practice in sunflower production.

The hybrid NS-H-111 showed excellent adaptability to variable weather conditions. The hybrid Dukat, with the average yield of 3.79 t/ha in irrigation, showed to be suitable for late cropping and double cropping in irrigation. 


\section{REFERENCE}

Bošnjak, Đ., Marinković, R., 1992. Sunflower requirement for water in the chernozem zone of Yugoslavia. Proceedings of $13^{\text {th }}$ International Sunflower Conference, Pisa, Italy, Vol. 1, 57-63.

Bošnjak, Đ., 1993. Potencijalna evapotranspiracija suncokreta u klimatskim uslovima Vojvodine. Savremena poljoprivreda Vol. 40, Br. 5, 51-53.

Cox, W.J., Jolliff, G.D., 1986. Growth and Yield of Sunflower and Soybean under Soil Water Deficits. Agron. J. Vol. 78, No 2, 226-230.

Crnobarac, J., Škorić, D., Marinković, R., Dušanić, N., 1997. Privredni značaj, sorte i tehnologija proizvodnje suncokreta. Savremena poljoprivredna tehnika, Vanredni broj sa radovima V naučnog skupa "Pravci razvoja poljoprivredne tehnike", 178-198.

Dragović, S., 1992. Uticaj navodnjavanja i rokova setve na prinos i kvalitet nekih hibrida suncokreta. Zbornik savetovanja o unapređenju uljarstva Jugoslavije, Beograd, 41-53.

Dragović, S., Maksimović, Livija, 1995. Drought phenomenon and impact on crop yields in the Vojvodina Province, Yugoslavia. Proceedings of the International Workshop on Drought in the Carpathian Region, Budapest, 207-217.

Dragović, S., Maksimović, Livija, Karagić, Đ., 1996. Effect of sprinkler and furrow irrigation on sunflower seed yield and quality. Proceedings of $14^{\text {th }}$ International Sunflower Conference, Beijing-Shenyang, PR China, Vol. 1, 389-394.

Dragović, S., Maksimović, Livija, Karagić, Đ., 1997. Navodnjavanje suncokreta i njegova uloga u povećanju i stabilizaciji prinosa. Savremena poljoprivredna tehnika, Vanredni broj sa radovima V naučnog skupa "Pravci razvoja poljoprivredne tehnike", 245-254.

Flagella, Z., Rotunno, T., Tarantino, E., Di Caterina, R., De Caro, A., 2002. Changes in seed yield and oil fatty acid composition of high oleic sunflower (Helianthus annuus L.) hybrids in realation to the sowing date and the water regime. European Journal of Agronomy 17, 221-230.

Gatto, I., Greco, I., Alba, A., 1980. The effects of Seasonal Irrigation Water Regimes in Sunflower Characters in Southern Italy. $9^{\text {th }}$ Int. Sunflower Confernce, Malaga, Spain.

Goksoy, A.T., Demir, A.O., Turan, Z.M., Dagustu, N., 2004. Response of sunflower (Helianthus annuus L.) to full and limited irrigation at different growth stages. Field Crops Research 87, pp. 167-178.

Maksimović, Livija, Dragović, S., 1997. Impact of drought and effect of irrigation on yield and evapotranspiration of sunflower. Proceedings of International Symposium on Drought and Plant Production, Lepenski Vir, 233-241.

Maksimović, Livija, Karagić, Đ., Škorić, D., Dragović, S., 1998. Effect of irrigation on yield and evapotranspiration of NS sunflower hybrids. Proceedings of $2^{\text {nd }}$ Balkan Symposium on Field Crops, Novi Sad, Vol. 2, 507-512.

Plaut, Z., 1995. Sensitivity of crop plants to water stress at specific developmental stages: reevaluation of experimental findings. Israel Journal of Plant Sciences Vol. 43, 99-111.

Stone, L.R., Schlegel, A.J., Gwin, Jr., Khan, A.H., 1996. Response of sorn, grain sorghum and sunflower to irrigation in the High Plains of Kansas. Agricultural Water Management 30 251-259.

Škorić, D., 1988. Sunflower Breeding. Uljarstvo, Beograd, 1:1-99.

Škorić, D., Marinković, R., Ćupina, T., Jocić, B., Mihaljčević, M., Maširević, S., 1993. Analiza proizvodnje suncokreta u 1992. godini i predlog hibrida za narednu godinu na osnovu rezultata ostvarenih u makro ogledima. "Zbornik radova" Instituta za ratarstvo i povrtarstvo Novi Sad, Sv. 21, 181-197.

Škorić, D., Ćupina, T., Crnobarac, J., Maširević, S., 1996. Dostignuća u oplemenjivanju, fiziologiji, tehnologiji gajenja i zaštiti suncokreta (1965-1995. godina). Trideset godina Seminara agronoma 1965-1995, Naučni institut za ratarstvo i povrtarstvo, Novi Sad, 275291.

Škorić, D., Marinković, R., Jovanović, D., Jocić, S., 2001. Preporuka hibrida za setvu u 2001. godini na osnovu rezultata ostvarenih u makro i mikro ogledima i u masovnoj proizvodnji suncokreta. Zbornik referata, XXXV - Seminar agronoma, 191-199.

Škorić, D., Jocić, S., Marinković, R., Jovanović, D., Hladni, Nada, 2003. Ocena proizvodnih osobina NS-hibrida suncokreta na osnovu mikro ogleda. "Zbornik radova" Instituta za ratarstvo i povrtarstvo Novi Sad, Sv. 38, 171-180. 
Škorić, D., Joksimović, J., Jocić, S., Jovanović, D., Marinković, R., Hladni, Nada, Gvozdenović, Sandra, 2005. Ocena vrednosti produktivnih svojstava NS-hibrida suncokreta. "Zbornik radova" Instituta za ratarstvo i povrtarstvo Novi Sad, Sv. 41, 21-33.

Unger, W.P., 1990. Sunflower. Chapter 25 in Irrigation of Agricultural Crops. ASA-CSSA-SSSA, Madison, WI, USA, 775-794.

Vučić, N., Bošnjak, Đ., 1988. Yield and evapotranspiration ratio in irrigated and unirrigated sunflower. Proceedings of $12^{\text {th }}$ International Sunflower Conference, Novi Sad, Yugoslavia, Vol. 1, 446-448.

\section{ADAPTABILIDAD DE LOS HÍBRIDOS DE GIRASOL NS A LAS CONDICIONES CLIMÁTICAS DE CULTIVO CAMBIABLES}

\section{RESUMEN}

En Serbia, el girasol se cultiva en una superficie de alrededor de 150.000 a 200.000 ha, con un rendimiento promedio de 2,0 t/ha. La causa de variaciones del rendimiento anuales, son las precipitaciones desiguales y la distribución desigual. En las condiciones de riego en la producción se logran rendimientos de alrededor de 3 t/ha, y en los ensayos, de 4-5 t/ha.

En el período comprendido entre 2000 y 2004, en las condiciones de riego en el suelo tipo Chernoziom (suelo humífero), se investigaron 2 híbridos de girasol, desarrollados en el Instituto de Agricultura y Horticultura de Novi Sad.

En el año 2000, que fue de una sequía extraordinaria, los rendimientos promedios en las condiciones de riego, ascendían a 5,04 t/ha, y sin riego, a 3,97 t/ha. En el año 2001, con muchísimas lluvias, los rendimientos en las condiciones de riego, tanto como en las condiciones sin riego, fueron semejantes, alrededor de 3 t/ha. En el año 2002, que fue de sequía moderada, a pesar de cuatro riegos de $240 \mathrm{~mm}$, los rendimientos promedios en las condiciones de riego, tanto como en las condiciones sin riego, fueron semejantes, alrededor de 4,5 t/ha, debido a la presentación de una enfermedad. En el año 2003, sumamente caluroso y seco, se lograron rendimientos más bajos, debido al período de vegetación más corto, pero el efecto de riego promedio para ambos híbridos, ascendió a $27 \%$, y sólo para el híbrido Dukat, $51 \%$. Cuando el año es sumamente oportuno para la producción, como el año 2004, los rendimientos son uniformes y de buena calidad.

En ambos híbridos, el riego tuvo el impacto positivo en incremento de rendimiento del aceite, sobre todo en los años de sequía, lo que indica la justificación de la aplicación de esta medida en la producción de girasol, también.

El híbrido NS-H-111 demostró una gran adaptabilidad y estabilidad de rendimiento en el cultivo en las condiciones de medio ambiente cambiables, mientras que el híbrido Dukat resulta oportuno para la producción de la siembra tardía y cultivo doble en las condiciones de riego.

\section{ADAPTABILITÉ DES HYBRIDES DE TOURNESOL NS À DES CONDITIONS DE TEMPS VARIABLES}

RÉSUMÉ

Le tournesol est cultivé en Serbie sur une surface de 150000 à 200000 ha avec un rendement de 2,0 t/ha par année. Les variations de rendement sont 
dues à des précipitations inégales et défavorablement réparties. Avec l'irrigation, les rendements sont de 3 t/ha dans le secteur commercial et de 4-5 t/ha dans les champs expérimentaux.

Entre 2000 et 2004 deux hybrides de tournesol développés à l'institut de Novi Sad ont été cultivés dans un sol de type tchernoziom et soumis à l'irrigation pour ensuite faire l'objet d'une analyse.

En 2000, année exceptionnellement sèche, le rendement moyen des cultures soumises à l'irrigation a été de 5,04 t/ha tandis que celui des cultures qui n'étaient pas soumises à l'irrigation était de 3,97 t/ha. En 2001, année exceptionnellement pluvieuse, les rendements avec ou sans irrigation ont été semblables, c'est-à-dire d'environ 3 t/ha. En 2002, année modérément sèche les rendements moyens des cultures avec et sans irrigation (quatre irrigations, norme de $240 \mathrm{~mm}$ ) ont été semblables et d'environ 4,5 t/ha à la suite de l'apparition de maladies. En 2003, année exceptionnellement chaude et sèche, les rendements ont été réduits à cause d'une période de végétation abrégée. L'effet d'irrigation moyen pour les deux hybrides testés a été de $27 \%$ et de $51 \%$ pour l'hybride Dukat. En 2004, année très favorable à la production, les rendements ont été uniformes et de bonne qualité.

Dans le cas des deux hybrides, l'irrigation a eu un effet positif sur l'augmentation du rendement d'huile, surtout dans les années plus sèches, ce qui justifie l'utilisation de ces mesures dans la production du tournesol.

L'hybride NS-H-11 a montré une grande adaptabilité et une stabilité de rendement lorsque cultivé dans des conditions de temps variables. L'hybride Dukat s'est montré approprié à des semailles tardives et à une double récolte lorsque soumis à des mesures d'irrigation. 
